\title{
TECHNOLOGICAL CHARACTERIZATION OF Mezilaurus itauba WOOD: APPLICATION AND MACHINING TESTS
}

\author{
Jaime Vieira Rodrigues $^{1 *}$, Felipe Manzoni Barbosa ${ }^{2}$, Jaqueline Beatriz Brixner Dreyer ${ }^{3}$, Luís Paulo Baldissera \\ Schorr ${ }^{4}$, Tarik Cuchi $^{5}$, Monique Bohora Schlickmann ${ }^{6}$ \\ ${ }^{1 *}$ Universidade Federal de Santa Maria, Departamento de Ciências Florestais, Santa Maria, Rio Grande do Sul, Brasil, \\ *jaimearvores@gmail.com; \\ ${ }^{2}$ Universidade Federal do Paraná, Programa de Pós Graduação em Engenharia Florestal, Curitiba, Paraná, Brasil, \\ felipemanzonibarbosa@hotmail.com \\ ${ }^{3}$ Universidade Federal de Santa Maria, Programa de Pós Graduação em Engenharia Florestal, Santa Maria, Rio Grande do Sul, Brasil, \\ jaqueline.bbdreyer@gmail.com \\ ${ }^{4}$ Universidade Federal de Lavras, Programa de Pós Graduação em Engenharia Florestal, Lavras, Minas Gerais, Brasil, \\ 1p468@nau.edu \\ ${ }^{5}$ Universidade Estadual do Centro-Oeste, Programa de Pós Graduação em Ciências Florestais, Irati, Paraná, Brasil, \\ tarikcuchi@gmail.com \\ ${ }^{6}$ Universidade do Estado de Santa Catarina, Departamento de Ciências Florestais, Lages, Santa Catarina, Brasil, \\ moniqueschlickmann@gmail.com
}

Received for publication: 03/06/2019 - Accepted for publication: 31/03/2020

\begin{abstract}
Resumo
Caracterização tecnológica da madeira de Mezilaurus itauba: aplicação e testes de usinagem. O Brasil possui diversas espécies florestais com potencial produtivo de madeira sustentável. Porém a busca por materiais de qualidade tecnológica ainda é um desafio. A madeira é um excelente material de construção, entretanto, ainda existem poucos trabalhos para a caracterização tecnológica, usinagem e beneficiamento dessas espécies, dentre as quais está Mezilaurus itauba (Meisn.) Taub. Ex Mez. Assim, este estudo buscou avaliar as características tecnológicas e potencial de aplicação da madeira de M. itauba de dois lotes comerciais distintos, por meio de suas propriedades mecânicas e testes de usinagem. Para isso foram realizados testes de flexão estática, dinâmica e usinagem. Os resultados dos testes de compressão perpendicular às fibras avaliados apresentaram para o módulo de elasticidade valores médios de 9899,77 Mpa e 10670,74 Mpa respectivamente para lote 1 e lote 2. O valor médio observado para do módulo de ruptura do L1 foi de 96,02 Mpa enquanto para L2 foi observado um valor de 113,85 Mpa. Para os testes de cisalhamento foi observada pouca variação entre os corpos de prova bem como baixa variação entre os lotes avaliados. Quanto aos testes de usinagem a madeira de $M$. itauba ficou classificada como excelente para o uso na fabricação de móveis e aberturas internas. Os lotes de $M$. itauba, apresentam resistência mecânica aceitável e pela densidade é indicada para obras estruturais, bem como para a confecção de móveis e acabamento de interiores.
\end{abstract}

Palavras-chave: Madeira; qualidade tecnológica; módulo de elasticidade; cisalhamento, resistência.

\section{Abstract}

Brazil has several forest species that can be used for sustainable wood production. However, finding materials with technological quality is still a challenge. Wood is an excellent building material, however, there are few studies that have investigated the technological characterization, machining and processing of these species, including Mezilaurus itauba (Meisn.) Taub. Ex Mez. Thus, this study aimed to evaluate the technical characteristics and application potential of $M$. itauba wood from two distinct commercial lots, by analyzing its mechanical properties and performing machining tests. For this, static bending, dynamics and machining tests were carried out. The perpendicular compression tests of the evaluated fibers presented mean values of 9899.77 Mpa and 10670.74 Mpa for the elasticity module of lot 1 and lot 2, respectively. The average value observed for the L1 rupture module was $96.02 \mathrm{Mpa}$, while for L2 it was $113.85 \mathrm{Mpa}$. For the shear tests, low variation was observed between the specimens as well as between the evaluated lots. As for machining tests, $M$. itauba wood was classified as excellent for manufacturing furniture and internal openings. The M. itauba lots have acceptable mechanical strength, and the density is indicated for structural works, as well as for manufacturing furniture and interiors.

Keywords: Wood; technological quality; modulus of elasticity; shear, resistance.

\section{INTRODUCTION}

The global goods and services market is constantly changing, resulting in a growing demand for sustainable products (KHAN; MOHSIN, 2017). Nevertheless, the search for quality materials that are legally and sustainably produced is still a challenge, especially in Brazil, where there is a high diversity of tree species that could potentially be used in sustainable timber production management plans.

FLORESTA, Curitiba, PR, v. 51, n. 1, p. 037-043, jan/mar 2021.

Rodrigues, J. V. et.al.

ISSN eletrônico 1982-4688

DOI: $10.5380 /$ rf.v51 i1. 67247 
Despite its reduced use in Brazil, wood is an excellent sustainable building material (GRIEBELER et al., 2017). Brazilian forest species usually have wood with characteristics that allow them to adapt to different conditions of use, however, the practical applications of timber have been poorly studied (GOULART et al., 2012). Additionally, woody material is heterogeneous and anisotropic, therefore anatomical, physical, and mechanical characterization is important because it makes it possible to determine the technological properties (OLIVEIRA,2007) and application potentials of woods.

In this context, Mezilaurus itauba (Meisn.) Taub. Ex Mez. stands out among the most common timber species as its wood has good mechanical resistance, low retractability, high natural resistance to rot and insect attack (GARCIA et al., 2012), and has high commercial value in the export market (IMAZON, 2010). Despite information about the general characteristics of $M$. itauba wood, technological characterization could be the key to better understand its mechanical properties as well as the potential uses of this species. Thus, the characterization of static bending, dynamic bending and machining tests are necessary (SCANVANCA JUNIOR; GARCIA, 2004; MORESCHI, 2005; OAK; SILVA, U.S.; LATORRACA, 2010).

Although it is widely used in management plans, there are few studies about $M$. itauba wood, therefore, this study hypothesized that there would be little variability among the evaluated material, as well as sought to evaluate the technological characteristics and application potential of $M$. itauba wood from two distinct commercial lots by analyzing its mechanical properties and machining tests.

\section{MATERIAL AND METHODS}

\section{Wood origin}

Two distinct lots of M. itauba wood were selected from the Esquadrias Rodrigues company, located in the municipality of Júlio de Castilhos, Rio Grande do Sul, Brazil, which were obtained from a forest management plan in Juína, Mato Grosso, Brazil. Five boards (four centimeters thick and three meters long) were randomly chosen from the same position in each log to make the specimens used in the mechanical property tests.

The material was transported to the Universidade Federal de Santa Maria (UFSM) and stored in an airconditioned chamber at $20{ }^{\circ} \mathrm{C}$ and $65 \%$ relative humidity until the hygroscopic balance reached a moisture content of $12 \%$. For the static flexion tests, 50 samples with $2.5 \times 2.5 \times 41 \mathrm{~cm}$ dimensions in the radial, tangential, and longitudinal directions were used, with 25 pieces from each lot. For dynamic flexion tests, 50 samples $(25$ pieces per lot) were used, with $2 \times 2 \times 30 \mathrm{~cm}$ dimensions. For the machining tests, $2.5 \mathrm{~cm}$ thick boards with varied lengths were randomly selected and used to prepare $30-2.3 \times 12 \times 30 \mathrm{~cm}$ samples. This material was processed and evaluated using the equipment at the Esquadrias Rodrigues factory.

\section{Static flexion}

The static bending tests followed the American Society for Testing and Materials - ASTM D143-94 (1995) standard and were tested in an Amsler universal test machine, with 20 ton capacity and equipped with specific and automated accessories to obtain the data.

\section{Dynamic flexion}

To determine the apparent specific mass, the specimens were weighed on an analytical scale with $0.01 \mathrm{~g}$ precision and measured by the stereometric method. Then, the specific apparent mass corresponding to $12 \%$ humidity content was calculated from the following equation:

$$
A S M=\frac{P 12 \%}{V 12 \%}
$$

in which: ASM $12 \%=$ apparent specific mass at $12 \%$ humidity $\left(\mathrm{g} / \mathrm{cm}^{3}\right) ; \mathrm{p}=$ weight or mass at $12 \%$ humidity $(\mathrm{g})$; $\mathrm{v}=$ volume at $12 \%$ humidity $\left(\mathrm{cm}^{3}\right)$.

To perform the dynamic bending tests, the specimens were submitted to impact in their central region, in the $24 \mathrm{~cm}$ span of the machine, in a Charpy Pendulum. After obtaining the work absorbed (W) to break the specimens, the resilience coefficient (K) and dynamic dimension (CD) were calculated according to the equations of Moreschi (2005), as follows.

$$
K=\frac{W}{b * h}
$$

where: $\mathrm{K}=$ resilience coefficient $\left(\mathrm{Kgm} / \mathrm{cm}^{2}\right) ; \mathrm{W}=$ work absorbed to break the test body $(\mathrm{Kgm}) ; \mathrm{b}$ and $\mathrm{h}=$ the cross-section of the test body $(\mathrm{cm})$.

$$
D Q=K * A S M
$$

in which: DQ = dynamic quota $(\mathrm{kgf.cm} / \mathrm{g}) ; \mathrm{K}=$ resilience coefficient $\left(\mathrm{Kgm} / \mathrm{cm}^{2}\right) ; \mathrm{ASM}=$ apparent specific mass $\left(\mathrm{g} / \mathrm{cm}^{3}\right)$. 


\section{Machining tests}

The machining tests were performed according to the methodology described by the American Society for Testing and Materials - ASTM D 1666-87 (1994), along with the tear test, sanding test, straightening test, hinge drilling, pin-dowel drilling.

To evaluate the tear test, the main defect analyzed was the survey of the fibers, with notes assigned according to the intensity of the defect. The tear test was made on the side of the wood sample with a horizontal drill, mounted with a helical drill with $8 \mathrm{~mm}$ diameter. For the sanding test, a MacLinea band sander with a 115 $\mathrm{cm}$ and controlled track speed of $0.11 \mathrm{~m} / \mathrm{min}$ was used. Two devices were used for simultaneous sanding: one with 80 grain sandpaper and another with 100 grain sandpaper. The side opposite from that used for the straightening test was used for the sanding test, where defects scratching the surface and fuzzy grain were observed.

In the straightening test, samples were submitted to a plucking planer, containing three knives with rotation frequency of the knife door shaft of $3460 \mathrm{rpm}$, cutting thickness of $1.6 \mathrm{~mm}$ and $60^{\circ}$ angle of attack, with manually controlled track speed. With the knives properly sharpened, the specimens were randomly passed through the planer, both with and against the grain growth.

The drilling tests for dowels were done with a vertical bench drill, steel helical drill bits of 6, 8, and 12 $\mathrm{mm}$ diameters with two perforations per sample. The holes were made with $25 \mathrm{~mm}$ between them and the edges. For the hinge drilling test, the same drill was equipped with a $26 \mathrm{~mm}$ flat drill. Two holes were drilled, one through and the other non through, to observe the presence of grain crushing, fuzzy grain, and/or chip pulling.

To avoid mechanical variations, jigs were made to correctly position cuts and drill, as well as for experimental machining to establish feed speeds and adjust cutting tools, in order to evaluate all parts under similar conditions. After the tests, specimens were visually qualified by the evaluator. This involved assigning grades ranging from 1 to 5 (Table 1), calculated as the average values for each attribute evaluated.

Tabela 1 - Notas aplicadas nas avaliações das peças nos ensaios de usinagem.

Table 1 - Grades applied in the evaluations of the parts in the machining tests.

\begin{tabular}{ccc}
\hline Grades & Classification & Defects $(\%)$ \\
\hline 1 & Excellent & No defects \\
2 & Good & Less than 50 \\
3 & Regular & 50 \\
4 & Bad & More than 50 \\
5 & Unacceptable & 100 \\
\hline
\end{tabular}

\section{RESULTS}

\section{Static flexion}

The compression tests perpendicular to the wood fibers of the $M$. itauba lots presented average modulus of elasticity (MoE) values of 9899.77 Mpa and 10670.74 Mpa for lot 1 (L1) and lot 2 (L2), respectively (Figure 1 A). The mean value observed for the L1 rupture module was 96.02 Mpa, while 113.85 Mpa was observed for L2 (Figure 1 B).
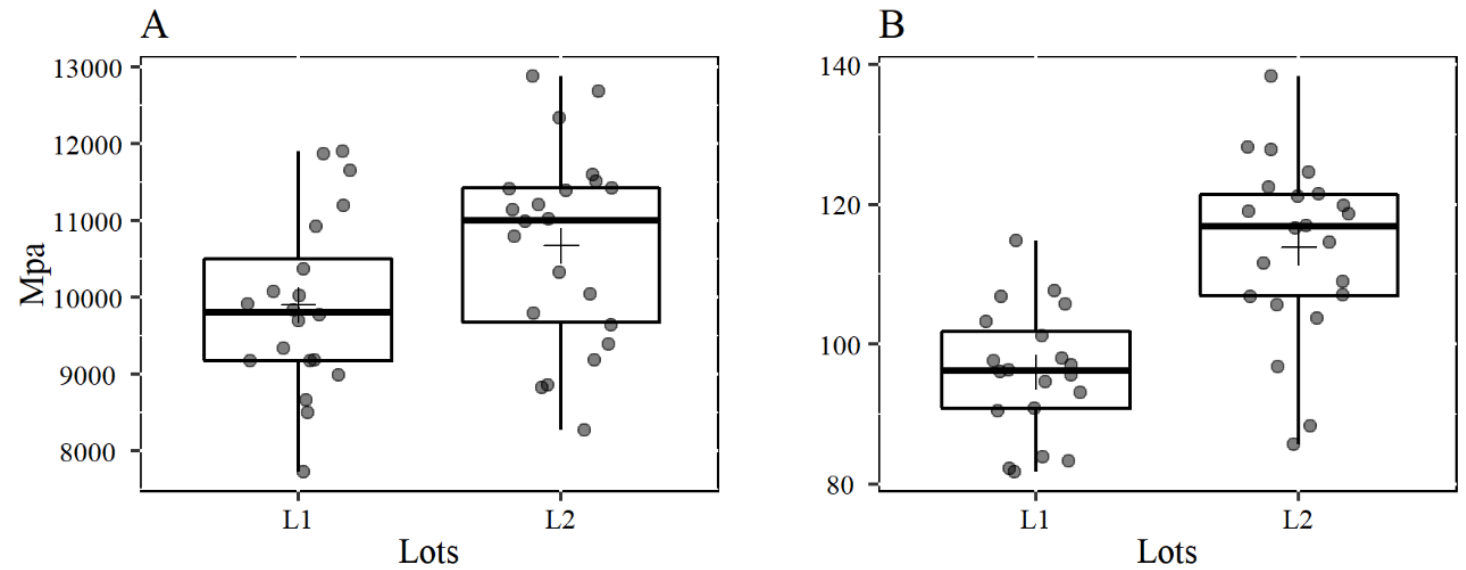

Figura 1: Valores obtidos para o módulo de elasticidade (A) e módulo de ruptura (B) em dois lotes de madeira de Mezilaurus itauba.

Figure 1: Values obtained for the modulus of elasticity (A) and rupture modulus (B) in two lots of Mezilaurus itauba wood. 


\section{Dynamic flexion}

For the shear tests, low variation was observed between the specimens as well as between the evaluated lots. In this sense, lot 1 presented the highest means for strength, resilience coefficient, and dynamic dimension (Figure 2, A, B, C). Although L1 presented lower means for apparent specific mass $0.75 \mathrm{~g} / \mathrm{cm}$, it had less variation when compared to L2, which presented the highest means and variation in values of the specimens for this attribute $\left(0.80 \mathrm{~g} / \mathrm{cm}^{3}\right.$, Figure 3$)$.
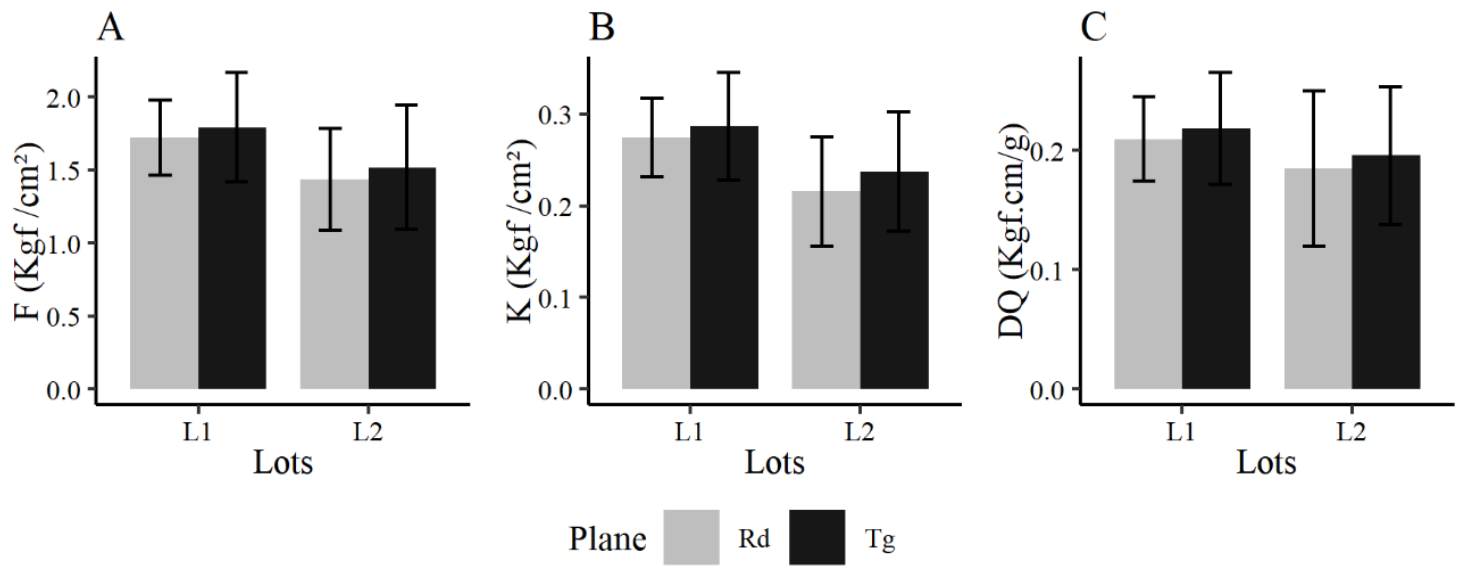

Figura 2: Valores obtidos para o teste de flexão dinâmica nos sentidos radial (Rd) e tangencial (TG) em dois lotes de madeira de Mezilaurus itauba. Onde: (A) Força, (B) Coeficiente de resiliência (D) Cota dinâmica.

Figure 2: Values obtained for the dynamic flexion tests in radial (Rd) and tangential (TG) planes in two lots of Mezilaurus itauba wood. Where: (A) Strength, (B) Resilience coefficient (C) Dynamic quota.

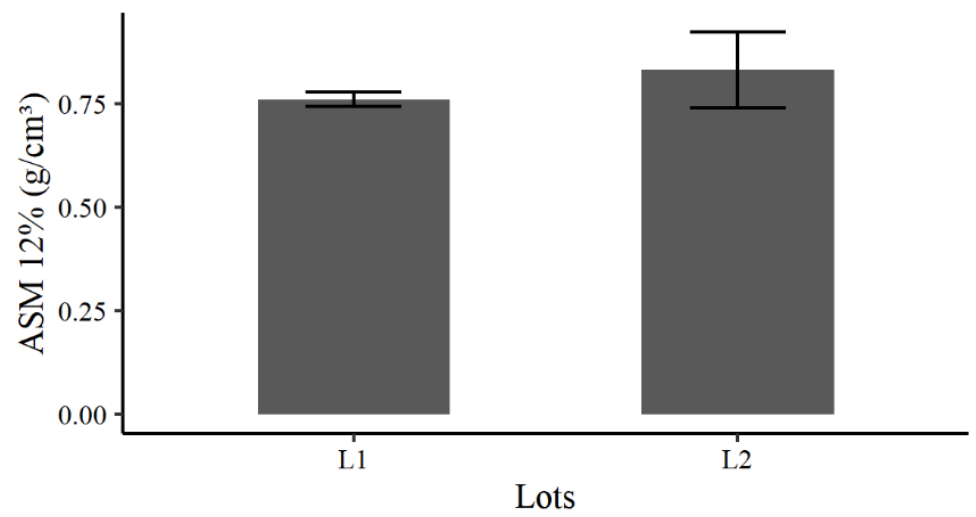

Figura 3: Valores obtidos para massa específica aparente a $12 \%$ de umidade em dois lotes de madeira de Mezilaurus itauba: L1: lote 1, L2: lote 2.

Figure 3: Values obtained for apparent specific mass at 12\% moisture in two batches of Mezilaurus itauba wood: L1: lot 1, L2: lot 2.

\section{Machining tests}

In the tear test (Tabela2), the initial and raised grain presented no lifting of fibers at the edges and bottom of the tear and was given an excellent score. According to the evaluation criteria after the sandpaper test, the grain of M. itauba was given an excellent score due to its low scratching and the effect of long grain and low effect of fuzzy grain (Table 2).

The straightening test presented a standard and homogeneous surface, free from defects after passing through the planer in the concordant and discordant directions of the fiber, in which the evaluated parameters of torn grain, long grain and fuzzy grain had mean values of $1.27,1.15$ and 1.12, respectively (Table 2 ). These values are considered excellent according to the classification used. 
Tabela 2: Resultados dos testes de rasgo horizontal, lixamento e desempeno.

Table 2: Results of the horizontal loom, sanding, and straightening tests.

\begin{tabular}{cccc}
\hline Test & Rated effect & Average & Classification \\
\hline \multirow{2}{*}{ Loom } & Grand Booted & 1,31 & Excellent \\
& Grand Raised & 1,04 & Excellent \\
\hline \multirow{2}{*}{ Sanding } & Scratching & 1,12 & Excellent \\
& Grand Long & 1,00 & Excellent \\
& Grand Felpuda & 1,23 & Excellent \\
\hline \multirow{2}{*}{ Straightening } & Grand Booted & 1,27 & Excellent \\
& Grand Long & 1,15 & Excellent \\
& Grand Felpuda & 1,12 & Excellent \\
\hline
\end{tabular}

In the evaluation of hinge tests with through and non-through holes, few effects of wood-burning, raised grain and pulled grain were observed thus being attributed to excellent classification (Table 3). Wood burning for the through hole averaged 1.46 since the inner edge of the hole was burnt in some specimens (Table 3 ).

Tabela 3: Resultados do teste de dobradiça furo passante e furo não passante.

Table 3: Results of the hinged test through-hole and non-through hole.

\begin{tabular}{cccc}
\hline Test & Rated effect & Average & Classification \\
\hline \multirow{2}{*}{ Hinge Through Hole } & Wood burning & 1,08 & Excellent \\
& Grand Raised & 1,04 & Excellent \\
& Grand Booted & 1,04 & Excellent \\
\hline \multirow{2}{*}{ Hinge Non-Through Hole } & Wood burning & 1,46 & Excellent \\
& Grand Raised & 1,00 & Excellent \\
& Grand Booted & 1,38 & Excellent \\
\hline
\end{tabular}

In the pin-dowel tests, less damage was observed when the $6 \mathrm{~mm}$ diameter drill bit was used. For the tests with $8 \mathrm{~mm}$ and $12 \mathrm{~mm}$ drills, there was an increase in the values of the evaluated parameters, which occurred due to an increased diameter of the drill bit, but did not affect the classification of the test (Table 4).

Tabela 4: Resultados para o teste de cavilha, com diâmetros de 6, 8 e $12 \mathrm{~mm}$.

Table 4: Results for the pin-dowel test, with diameters of 6, 8, and $12 \mathrm{~mm}$.

\begin{tabular}{cccc}
\hline Test & Rated effect & Average & Classification \\
\hline \multirow{2}{*}{ Pin-Dowel $6 \mathrm{~mm}$} & Grand Booted & 1,23 & Excellent \\
& Grand Raised & 1,77 & Excellent \\
\hline \multirow{2}{*}{ Pin-Dowel $8 \mathrm{~mm}$} & Grand Booted & 1,46 & Excellent \\
& Grand Raised & 1,96 & Excellent \\
\hline \multirow{2}{*}{ Pin-Dowel $12 \mathrm{~mm}$} & Grand Booted & 1,69 & Excellent \\
& Grand Raised & 1,85 & Excellent \\
\hline
\end{tabular}

\section{DISCUSSION}

The values of specific mass obtained for the $M$. itauba lots were 0.75 and $0.80 \mathrm{~g}^{\mathrm{cm}} \mathrm{cm}^{-3}$. In a study conducted with Amazonian commercial species, Silveira et al. (2013) found a specific mass of M. itauba ranging from 0.915 to $0.983 \mathrm{~g} . \mathrm{cm}^{-3}$, while Araújo (2007) found values of $0.70 \mathrm{~g} . \mathrm{cm}^{-3}$. Since the wood comes from different lots, variations in specific mass were expected. According to Foelkel et al. (1971) and Araújo (2007), the specific mass is an important factor for determining the physical properties and can vary between species and individuals of the same species from different regions. The mechanical characteristics of wood are influenced by specific mass as well as by dimensional stability. In this study, the specific mass of lot 2 was $0.80 \mathrm{~g} . \mathrm{cm}^{-3}$, which may have influenced the higher mean resistance of this lot in the static flexion evaluations of rupture modulus and modulus of elasticity (Figure 1).Furthermore, Souza et al. (2013) support that wood strength factors are positively correlated with increased specific mass.

FLORESTA, Curitiba, PR, v. 51, n. 1, p. 037-043, jan/mar 2021.

Rodrigues, J. V. et.al.

ISSN eletrônico 1982-4688

DOI: $10.5380 /$ rf.v51 i1. 67247 
Regarding the variability found for the specific mass of lot 2 compared to lot 1 , dynamic bending was higher in lot 1, which was unexpected seeing as Souza et al. (2013), in a study about dynamic bending of Patagonula americana L. and Ocotea catharinensis Mez, observed that the specific mass of these species increases proportionally with increased resistance to wood rupture for the parameters strength, resilience coefficient, and dynamic dimension.

When analyzing the shear resistance, the tangential section showed greater resistance even with the radial section under the influence of wood rays. According to Lobão et al. (2010), the anatomical structure as the diameter of the heat, fiber length is fundamental for explaining the variations existing in woods. According to IPT (2019), M. itauba has a small number of thin rays that provide greater resistance in this section. However, according to Beltrame et al. (2013), factors such as anatomy, dimension of the pieces, specific mass and slope of the grain negatively influence the wood in shear tests. In addition, woods with higher proportions of latewood and adult have greater resistance in the tangential section, corroborating the results obtained for these lots, since the wood comes from forests managed with a selection of mature trees for cutting.

The machining tests performed on $M$. itauba wood were satisfactory. Despite the lack of studies about machining for this species, Fernandes et al. (2011) highlight wood machining should be carried out with diamond tools due to the strength of the wood. Since there were good results for the sanding test, $M$. itauba wood can be used for projects with a higher finish of the final product.

For the straightening test, the good results are due to the high rotation of the cylinder door knives, associated with the advancement speed, which although manually controlled, was low and correlated to the low depth of cut, in addition to knife edges being optimally sharpened. According to Zamarian, Albuquerque and Matos, (2012), when the machines are manually controlled, they must be operated in the best possible way to prevent damages such as wood burns.

The hinge test with through-hole was rated excellent due to the low presence of defects in the machined parts. Wood burning for a through hole obtained an average of 1.46 due to the burning on the inner edge, which may have been obtained due to the lack of mechanical control during the procedure. According to Zamarian, Albuquerque and Matos, (2012), Mimosa scabrella Benth lots were burnt after machining processes without mechanical control of machine advancement. The greatest defects were observed in the pin-dowel test due to increased diameter of the drill bit, corroborating the results of Carvalho, Silva and Latorraca, (2010) who found regular evaluation for this parameter when evaluating the machining of Kharya ivoriensis A. Chev. .

The value obtained for the MoE of $M$. itauba classifies the species into the C 20 resistance class (NBR), which disqualifies it for structural works (ABNT NBR 7190, 1997). However, Lobão et al. (2010) classifies this species for use in high civil construction and floors because of the density and anatomical characteristics of the wood, corroborating with Araújo (2007), who classified the wood of this species as resistant since most of the mechanical properties are associated with increased specific mass. In this sense, only the NBR classification (ABNT NBR 7190, 1997) is insufficient for determining the potential use of $M$. itauba, since other authors found similar values for the specific mass, thus the proper dimensioning of the pieces could be fundamental for construction and structural purposes. Additionally, the machining tests confirm the suitability of M. itauba wood for general carpentry of interior finishes and furniture manufacturing.

\section{CONCLUSIONS}

- The evaluated lots presented low variability in their physical and mechanical properties.

- The evaluated $M$. itauba lots presented acceptable mechanical resistance for interior works and are indicated for structural works when used in appropriate dimensions.

- M. itauba wood is indicated for manufacturing furniture and interiors, however, when necessary finishing and machining of the final product should be used.

\section{REFERENCES}

ARAÚJO, H. J. B. de. Relações funcionais entre propriedades físicas e mecânicas de madeiras tropicais brasileiras. Floresta, Curitiba, v. 37, n. 3, p. 399-416, 2007.

AMERICAN SOCIETY FOR TESTING AND MATERIALS. ASTM D 1666 - 87. Standard method for conducting machining tests of wood and wood base materials. Philaldelphia, 226-245, 1995.

ASSOCIAÇÃO BRASILEIRA DE NORMAS TÉCNICAS. NBR 7190: projeto de estruturas de madeira. Rio de Janeiro, 1997.

FLORESTA, Curitiba, PR, v. 51, n. 1, p. 037-043, jan/mar 2021.

Rodrigues, J. V. et.al.

ISSN eletrônico 1982-4688

DOI: $10.5380 /$ rf.v51 i1. 67247 
BELTRAME, R.; MATTOS, B. D.; GATTO, D. A.; LAZAROTTO, M.; HASELEIN, C. R. Resistência ao choque da madeira de Platanus x acerifolia em diferentes condições de umidade, Revista Árvore, Viçosa, v. 37, n. 4, p. 771-778, 2013.

CARVALHO, A. M. de; SILVA, B. T. B. da; LATORRACA, J. V. de F. Avaliação da usinagem e caracterização das propriedades físicas da madeira de mogno africano (Khaya ivorensis A. Chev.), Cerne, Lavras, v. 16, p. 106$114,2010$.

FERNANDES, J. A.; CASANOVA, C. A. M.; TEIXEIRA, C. R.; BALZARETTI, N. M. Diamond tools for wood processing. Estudos tecnológicos em engenharia, São Leopoldo, v. 7, n. 1, p. 55-70, 2011.

FOELKEL, C. E. B.; BRASIL, M. A. M.; BARRICHELO, L, E, G. Métodos para determinação da massa específica básica de cavacos para coníferas e folhosas. Piracicaba: IPEF, 1971.

FRANÇA, T. S. F. A.; ARANTES, M. D. C.; PAES, J. B.; VIDAURRE, G. B.; OLIVEIRA, J. T. da S.; PEREIRA BARAÚNA, E. E. P. Características anatômicas e propriedades físico-mecânicas das madeiras de duas espécies de mogno-africano. Cerne, Lavras, v. 21, n. 4, p. 633-640, 2015.

GARCIA, F. M.; MANFIO, D. R.; SANSÍGOLO, C. A.; MAGALHÃES. P. A. D. Rendimento no desdobro de toras de Itaúba (Mezilaurus itauba) e Tauari (Couratari guianensis) segundo a classificação da qualidade da tora, Revista Floresta e Ambiente, Seropédica, v. 19, n.4, p.468-474, 2012.

GOUlART, S. L.; MORI, F. A.; RIBEIRO, A. de O.; COUTO, A. M.; ARANTES, M. D. C.; MENDES, L. M. Análises químicas e da massa específica básica da madeira de raiz, fuste e galho de barbatimão [(Stryphnodendron adstringens) Coville] de bioma Cerrado. Cerne, Lavras, v.18, n. 1, p, 59-66. 2012.

GRIEBELER, A. M; BARBOSA F. M; MELLER. G; TURCHETTO, F. Potencial da madeira como material de construção sustentável. In: OLIVEIRA, T. D. DE (Ed.). Coleção - educação, espaço construído e tecnologias: Reflexões, Desafios e Perspectivas. 1. ed. Curitiba: Editora CRV, 2017. p. 311-320.

IMAZON - Instituto do Homem e Meio Ambiente da Amazônia/Equipe Técnica do IMAZON. Boletim de Preços de Madeira. Belém p:04, 2010.

IPT - Instituto de Pesquisas Tecnológicas do Estado de SP. Informações sobre madeiras: Itaúba. Disponible in:< http://www.ipt.br/informacoes_madeiras3.php?madeira=39> Accessed in 22 Feb 2019.

KHAN, S.N.; MOHSIN, M. The power of emotional value: Exploring the effects of values on green product consumer choice behavior. Journal of Cleaner Production, Amsterdam, v. 150, p. 65-74, 2017.

LOBÃO, M. S; CHAGAS, M. P; COSTA, D. de S. P; FERREIRA, A. T. B; SETTE JR, C. R; CARVALHO, I. L; FO, M. T. Agrupamento de espécies florestais pela similaridade das características físico-anatômicas e usos da madeira. Cerne, Lavras, v. 16, p. 97-105, 2010.

MORESCHI, J. C. Propriedades tecnológicas da madeira - manual didático. Universidade Federal do Paraná, Curitiba. p. 124, 2005

OLIVEIRA, J. T. S., N. C. FIDELER, M. NOGUEIRA, Tecnologias aplicadas ao setor madeireiro. Suprema Gráfica e Editora Ltda. 2007.

SCANVANCA, J. L; GARCIA, J. N. Determinação das propriedades físicas e mecânicas da madeira de Eucalyptus urophylla. Scientia Forestalis, Piracicaba, v. 27, n.5, p.723-733, 2004.

SILVEIRA, L. H. C.; REZENDE, A. V.; VALE, A. T. do. Teor de umidade e massa específica básica da madeira de nove espécies comerciais amazônicas. Acta amazônica, Manaus, v.43, n.2, p.179 - 184, 2013.

SOUZA. J. T.; FILIPINI, F. R.; BORTOLUZI, R. N. G.; BELTRAME, R.; VIVIAN, M. A.; MENEZES, W. M. Comportamento da flexão dinâmica na madeira de Patagonula americana L. e Ocotea catharinensis Mez. Revista Ciência da Madeira, Santa Maria v.4, n.2, p. 228-237, 2013.

ZAMARIAN, E. H. C.; ALBUQUERQUE, C. E. C. de; MATOS, J. L. M. de. Usinagem da madeira de bracatinga para uso na indústria moveleira. Floresta, Curitiba v. 42, n. 3, p. 631-638, 2012.

FLORESTA, Curitiba, PR, v. 51, n. 1, p. 037-043, jan/mar 2021.

Rodrigues, J. V.et.al.

DOI: $10.5380 /$ rf.v51 i1. 67247 